DOI: $10.19195 / 0524-4544.326 .11$

MATEUSZ PAPLICKI

ORCID: 0000-0002-4169-9298

Uniwersytet Medyczny we Wrocławiu

PAULINA CHROBAK

ORCID: 0000-0001-7439-7301

Kancelaria Radcy Prawnego Probitas Paulina Chrobak-Fic, Wrocław

MAREK PONIATOWSKI

ORCID: 0000-0003-3430-8882

Ochotnicza Straż Pożarna w Siechnicach

\title{
Prywatyzacja wykonania zadania ochrony przeciwpożarowej przez gminę
}

\section{Ochrona przeciwpożarowa jako zadanie publiczne gminy}

Pojęcie ,zadanie publiczne” niejednokrotnie jest używane zamiennie z takimi pojęciami, jak „kompetencja”, „zakres działania” czy „właściwości”. Mają one jednak szersze znaczenie od „zadania" i tworzą odrębną kategorią prawną, wywołując dalej idące skutki prawne ${ }^{1}$. Według M. Elżanowskiego „zadanie” zawiera w sobie tylko element obowiązku, gdy tymczasem pojęcie kompetencji odnosi się zarówno do zespołu uprawnień, jak i obowiązków². Zdaniem A. Walszak-Pyzioł kompetencje określają, jaki organ, w jakich formach i trybie może ustalić zadania oraz kontrolować, nadzorować lub kierować ich realizacją. Zakres zadań organu

1 L. Zacharko, Prywatyzacja zadań publicznych gminy. Studium administracyjnoprawne, Katowice 2000, s. 13.

${ }^{2}$ M. Elżanowski, Kompetencje rad nadzorczych i terenowych organów administracji państwowej, [w:] Terenowe organy administracji i rady narodowe po reformie, red. J. Służewski, Warszawa 1977, s. 213. 
administracji publicznej jest zdeterminowany normami określającymi jego kompetencje ${ }^{3}$.

\section{J. Boć określa kompetencje}

jako konstrukcję łączącą prawo z prawną formą działania administracji. Istnieją przy tym dwie możliwości badawcze problematyki kompetencji, tj. ujęcie statyczne obrazujące wyłączenie wszystkich kompetencji z całości porządku prawnego. Wyłączenie to może być odniesione do określonej kategorii organów czy określonego organu. Płaszczyzna ujęcia statystycznego daje możność odniesienia całości wszystkich kompetencji organów administracyjnych do ogólnego celu i całości zadań stawianych administracji w prawie. Drugą płaszczyzną jest ujęcie dynamiczne, definiujące kompetencje jako zdolność organu administracyjnego do skonkretyzowanego aktualizowania potencjalnego obowiązku działania sformułowanego przez prawo. Kompetencje są zawsze regulowane prawem, są równoznaczne z obowiązkiem i służą organowi w określonym uwarunkowaniu, przez to nie mają charakteru bezwzględnego, oderwanego zarówno od całokształtu różnorakich stosunków w państwie i społeczeństwie ${ }^{4}$.

Pojęcie zadania publicznego jest zawsze ograniczone normami prawnymi. Samo państwo decyduje, co jest, a co nie jest zadaniem publicznym. Za realizację danego zadania publicznego $\mathrm{w}$ świetle prawa odpowiedzialność ponosi państwo lub samorząd terytorialny, przy czym wykonywanie zadań nie musi odbywać się w ramach struktur organizacyjnych administracji publicznej ${ }^{5}$.

Według H. Gronkiewicz-Waltz jedną z cech organu państwowego jest istnienie celu, dla którego organ funkcjonuje. Zadania zaś stanowią konkretyzację celu organu państwowego określonego przepisami prawa ${ }^{6}$.

Trybunał Konstytucyjny uchwałą z dnia 27 września 1994 roku (sygn. K. $10 / 93)^{7}$ stwierdził, że wszystkie zadania samorządu terytorialnego mają charakter zadań publicznych $\mathrm{w}$ tym znaczeniu, że służą zaspokojeniu potrzeb zbiorowych społeczności lokalnych (w przypadku zadania własnego) lub społeczeństwa zorganizowanego w państwo (jak w przypadku zadań zleconych). Podobny pogląd wyraził Sąd Najwyższy, który w uzasadnieniu do wyroku z dnia 8 lutego $1996 \mathrm{roku}^{8}$ określił, że wszystkie zadania samorządu terytorialnego mają charakter zadań publicznych ze względu na to, że służą zaspokojeniu potrzeb zbiorowych społeczności.

${ }^{3}$ Zob. A. Walaszek-Pyzioł, Samodzielność prawna przedsiębiorstwa państwowego, Kraków 1984, s. 49 n.

${ }^{4}$ Por. J. Boć, Obywatel wobec ingerencji współczesnej administracji, Wrocław 1985, s. 123 n.; Prawo administracyjne, red. J. Boć, Wrocław 2010, s. 140-141.

5 Zob. S. Biernat, Prywatyzacja zadań publicznych, Warszawa-Kraków 1994, s. 29-30.

${ }^{6} \mathrm{H}$. Gronkiewicz-Waltz, Rola ministra przemystowego w zarzadzaniu gospodarka państwo$w a$, Warszawa 1985, s. 20-21.

7 Orzeczenie Trybunału Konstytucyjnego z dnia 27 września 1994 roku, K. 10/93, OTK 1994, cz. 2, poz. 46 .

8 Wyrok Sądu Najwyższego z dnia 8 lutego 1996 roku, III ARW 64/95, „Wspólnota” 1996, nr 43, s. 26. 
Samorząd terytorialny wypełnia przestrzeń przewidzianą dla państwa na danym obszarze. Zgodnie z art. 163 ust. 1 Konstytucji $\mathrm{RP}^{9}$ wykonuje on zadania publiczne niezastrzeżone przez Konstytucję lub ustawy dla organów innych władz publicznych ${ }^{10}$. Artykuł 164 ust. 1 określa, że to gmina ${ }^{11}$ jest podstawową jednostką samorządu terytorialnego. Zdaniem L. Zacharko można stwierdzić, że istnieje zależność między zadaniami publicznymi i zadaniami samorządu gminnego, ponieważ samorząd gminy wykonuje zadania publiczne i jest ich nośnikiem ${ }^{12}$. Potwierdza to art. 166 ust. 1 Konstytucji RP, który stanowi, że zadania publiczne służące zaspokojeniu potrzeb wspólnoty samorządowej są wykonywane przez jednostkę samorządu terytorialnego jako zadania własne.

Wśród jednostek samorządu terytorialnego najszerszy katalog zadań związanych z zaspokajaniem potrzeb wspólnoty ma gmina. Katalog ten wyznacza art. 7 ustawy z dnia 8 marca 1990 roku o samorządzie gminnym ${ }^{13}$ (dalej: u.s.g), który do zadań własnych gminy zalicza między innymi kwestie: ładu przestrzennego, gospodarki nieruchomościami, ochrony środowiska i przyrody, gospodarki wodnej; wodociągów i zaopatrzenia w wodę, kanalizacji, usuwania i oczyszczania ścieków komunalnych, utrzymania czystości i porządku oraz urządzeń sanitarnych, wysypisk i unieszkodliwiania odpadów komunalnych, zaopatrzenia w energię elektryczną i cieplną oraz gaz; lokalnego transportu zbiorowego; ochrony zdrowia czy porządku publicznego i bezpieczeństwa obywateli oraz ochrony przeciwpożarowej i przeciwpowodziowej, w tym wyposażenia i utrzymania gminnego magazynu przeciwpowodziowego.

9 Konstytucja Rzeczypospolitej Polskiej z dnia 2 kwietnia 1997 roku uchwalona przez Zgromadzenie Narodowe w dniu 2 kwietnia 1997 roku, przyjęta przez Naród w referendum konstytucyjnym w dniu 25 maja 1997 r., podpisana przez Prezydenta Rzeczypospolitej Polskiej w dniu 16 lipca 1997 roku (Dz.U. z 1997 r. Nr 78, poz. 483 ze. zm.).

10 Zob. L. Kieres, Samorzadowy sektor gospodarczy, [w:] J. Grabowski et al., System Prawa Administracyjnego, t. 8B. Publiczne prawo gospodarcze, red. R. Hauser, Z. Niewiadomski, A. Wróbel, Warszawa 2013, $58 \mathrm{n}$.

11 W myśl art. 1 ust. 1 i 2 ustawy z dnia 8 marca 1990 roku o samorządzie gminnym (Dz.U. z 1990 r. Nr 16, poz. 95 ze zm.) jej mieszkańcy tworzą z mocy prawa wspólnotę samorządową, a ilekroć w przepisach ustawy jest mowa o gminie, należy przez to rozumieć wspólnotę samorządową oraz odpowiednie terytorium. Artykuł 2 ust. 2 ustawy o samorządzie gminnym jednoznacznie wskazał, że gmina ma osobowość prawną, stając się podmiotem mienia komunalnego, niezbędnego do realizacji przypisanych jej zadań. Gmina jako osoba prawna działa poprzez swoje organy, którymi — zgodnie z przepisami art. 11a ustawy — są rada gminy oraz wójt (burmistrz, prezydent miasta). Wójt jako organ wykonawczy gminy wykonuje uchwały organu stanowiącego gminy (rady gminy), gospodaruje mieniem komunalnym, zajmuje się budżetem oraz realizuje zlecone gminie zadania z zakresu administracji rządowej - T. Kocowski, Gmina a Ochotnicze Straże Pożarne w wykonywaniu zadań w zakresie ochrony przeciwpożarowej, [w:] Prawo i administracja wobec wspótczesnych problemów spolecznych i gospodarczych, red. T. Kocowski, W. Małecki, „Prawo” 323, 2017, s. 102-103.

12 L. Zacharko, op. cit., s. 17.

13 Tekst jedn. Dz.U. z 2018 roku poz. 994 ze zm. 
Państwo pod wpływem czynników politycznych decyduje, które zadania publiczne będzie realizowało przez swoje organy, a które przekaże innym podmiotom władzy publicznej czy też podmiotom niepublicznym. W przypadku niektórych zadań publicznych (na przykład zaspokojenia potrzeb związanych z ochroną przeciwpożarową) zadania te stają się nie tylko lokalne, lecz także regionalne czy centralne, a nawet globalne ${ }^{14}$. Ciągła presja jednostek, na których rzecz administracja publiczna wykonuje zadania, sprawia, że cały czas pojawiają się nowe problemy do rozwiązania, co prowadzi do weryfikacji i poszerzenia katalogu zadań publicznych ${ }^{15}$.

Administracja rządowa i samorządowa realizują wiele zadań publicznych. W konfrontacji z nowymi problemami do rozwiązania, szybko zmieniającą się rzeczywistością społeczną oraz rosnącymi potrzebami społeczeństwa nie są one w stanie wykonać wszystkich przyjętych zadań. Można zatem uznać, że optymalnym rozwiązaniem jest uwolnienie się od wykonywania tych zadań poprzez przekazanie ich podmiotom prywatnym ${ }^{16}$.

\section{Prywatyzacja wykonania zadania publicznego}

Zdaniem A. Borkowskiego nie jest obecnie podważane, że organy władzy publicznej (w sytuacji niezastrzeżonej ustawą) mają pewną swobodę w zakresie wyboru formy organizacyjno-prawnej realizacji swych zadań publicznych. Kluczowym czynnikiem wyboru jest efektywność (sprawność, skuteczność, szybkość i jakość) wykonania zadania publicznego ${ }^{17}$.

Mając na uwadze konstytucyjną zasadę subsydiarności, można stwierdzić, że najdalej idącą formą jej realizacji w przypadku zadań publicznych jest prywatyzacja tego zadania ${ }^{18}$ lub przynajmniej jego wykonywania. Należy pamiętać,

14 J. Dobkowski, Struktura interesu społecznego a zasady rozdzielenia odpowiedzialności publicznoprawnej w administracji, [w:] Jednostka, państwo, administracja. Nowy wymiar, red. E. Ura, Rzeszów 2004, s. 106.

15 J. Korczak, D. Cedrowicz, Dywersyfikacja zadań samorządu terytorialnego, [w:] Organizacja administracji publicznej z perspektywy powierzonych jej zadań, red. T. Bąkowski, Warszawa 2015, s. 130.

16 A. Błaś, Formy działania administracji w warunkach prywatyzacji zadań publicznych, [w:] Administracja i prawo administracyjne u progu trzeciego tysiaclecia. Materiaty konferencji naukowej katedr prawa i postępowania administracyjnego, Łódź 2000, s. 23.

${ }^{17}$ A. Borkowski, Interes publiczny a partnerstwo publiczno-prywatne, [w:] Prawne aspekty prywatyzacji, red. J. Blicharz, Wrocław 2012, s. 447.

18 Prywatyzacja zadań publicznych oznacza przeniesienie realizacji zadania i stanowi przejaw wszelkiego odstępstwa od wykonania zadań przez podmioty administracji publicznej działające w formach prawa publicznego. Zob. na ten temat m.in. K. Bandarzewski, Prywatyzacja zadań publicznych, [w:] Koncepcja systemu prawa administracyjnego, red. J. Zimmermann, Zakopane 24-27 września 2006 r., Warszawa 2007, s. 331 n.; J. Zimmermann, Prawo administracyjne, Kra- 
że przejęcie przez podmioty spoza systemu administracji publicznej wykonania przekazanych im zadan ${ }^{19}$ nie powoduje, że tracą one status zadań publicznych ${ }^{20}$, dalej takimi pozostają. Zmienia się tylko sposób ich wykonania przez państwo: z bezpośredniego na pośredni. Zamiast czynności polegających na organizowaniu i wykonywaniu zadań przez organy, przedsiębiorstwa publiczne, zakłady administracyjne, mamy czynności polegające na kontroli, nadzorowaniu oraz wspieraniu lub inspirowaniu podmiotów niepublicznych ${ }^{21}$.

Proces prywatyzacji zadań publicznych jest niewątpliwie czynnikiem racjonalizującym działania administracji publicznej, albowiem podmioty prywatne efektywniej gospodarują środkami finansowymi ${ }^{22}$. L. Zacharko dodaje, że w prywatyzacji idzie nie tylko o redukcję zadań administracji publicznej, lecz o zapewnienie jednocześnie efektywniejszej ich realizacji ${ }^{23}$.

Niewątpliwie kwestia prywatyzacji wykonywania zadań publicznych, nie mówiąc o samej prywatyzacji wykonywania tych zadań, jest bardzo kontrowersyjna. Prywatyzacja, a być może początkowo prywatyzacja wykonania zadania publicznego, wbrew obiegowej opinii nie jest remedium na wszelkie niedoskonałości i zastosowanie jej nie zmieni automatycznie istniejącego stanu rzeczy ${ }^{24}$. T. Kocowski dodaje, że zadań publicznych służących zaspokojeniu potrzeb określonych społeczności obecnie nie da się zaspokoić wyłącznie poprzez wykorzy-

ków 2005, s. 143 n.; E. Ura, E. Ura, Prawo administracyjne, Warszawa 2002, s. 177 n.; M. Stahl, Instytucje zlecenia funkcji z zakresu administracji publicznej i prywatyzacja zadań publicznych, [w:] Prawo administracyjne. Pojęcia, instytucje, zasady w teorii i orzecznictwie, red. Z. Duniewska et al., Warszawa 2016, s. $300 \mathrm{n}$.

19 Procesu redukowania zadań państwa czy jednostek samorządu terytorialnego dokonuje się zazwyczaj przez:

— przekazanie zadań samorządom terytorialnym oraz samorządom zawodowym, jak również tak zwanym organizacjom pozarządowym;

— sprzedaż podmiotom prywatnym przedsiębiorstw i instytucji państwowych wykonujących zadania państwowe;

— zawieranie kontraktów z prywatnymi spółkami na realizację zadań jako usług publicznych. Zob. A. Błaś, Prywatyzacja zadań samorzadu terytorialnego, [w:] Studia nad samorządem terytorialnym, red. A. Błaś, Wrocław 2002, s. 360.

20 Por. T. Bąkowski, Administracyjnoprawna sytuacja jednostki w świetle zasady pomocniczości, Kraków 2007, s. 186.

21 S. Biernat, op. cit., s. 29-30.

22 Por. E. Knosala, Zadanie wspótczesnej administracji publicznej, [w:] Ustrojowo-prawne instrumenty polityki społecznej, red. M. Baron-Wiaterek Gliwice 2005, s. 46; S. Pieprzny, E. Ura, M. Ura, Umowy o partnerstwie publiczno-prywatnym jako czynnik efektywności i sprawności dziatań samorządu terytorialnego, [w:] Sprawność działań administracji samorządowej, red. E. Ura, Rzeszów 2006, s. 502 n.; T. Kocowski, Partnerstwo publiczno-prywatne w praktyce samorzadu terytorialnego, [w:] Funkcjonowanie systemu zamówień publicznych — aktualne problemy i propozycje rozwiąań, X Konferencja Naukowa, 26-27 czerwca 2017 r., Białystok, Warszawa 2017, s. 39 n.

23 L. Zacharko, op. cit., s. 28.

24 T. Kocowski, M. Paplicki, Ratownictwo medyczne - czy wyłacznie państwowe?, [w:] Prawne aspekty prywatyzacji, s. 200. 
stanie przedsiębiorstw publicznych i stosowanie władczych form działania. Konieczne jest zatem włączenie w proces ich realizacji podmiotów gospodarczych, które reprezentują różne formy organizacji i własności ${ }^{25}$.

Realizowanie niektórych zadań publicznych związane jest z koniecznością prowadzenia działalności, która może być określona jako gospodarcza i tym samym wymagać zazwyczaj kreowania nowych podmiotów mogących realizować taką działalność. Kreowanie podmiotów gospodarczych przez gminę celem realizacji określonych zadań publicznych ma służyć przede wszystkim znalezieniu odpowiedniej formy do prawidłowej realizacji zadań ciążących na tym podmiocie prawa publicznego ${ }^{26}$.

Działalność gospodarcza gmin skupia się w głównej mierze ${ }^{27}$ na wykonywaniu zadań o charakterze użyteczności publicznej. Zgodnie z art. 9 ust. 4 u.s.g. zadaniami użyteczności publicznej są zadania własne gminy, określone w art. 7 ust. 1, których celem jest bieżące i nieprzerwane zaspokajanie zbiorowych potrzeb ludności w drodze świadczenia usług powszechnie dostępnych. W celu realizacji tych zadań gmina może tworzyć jednostki organizacyjne, a także zawierać umowy z innymi podmiotami, w tym pozarządowymi (art. 9 ust. 1 u.s.g). Formy prowadzenia gospodarki gminnej, w tym wykonywania przez gminę zadań o charakterze użyteczności publicznej (art. 9 ust. 3 u.s.g.), określa ustawa z dnia 20 grudnia 1996 roku o gospodarce komunalnej (dalej: u.g.k.) ${ }^{28}$.

Gospodarka komunalna wiąże się z zaspokajaniem potrzeb ludności wynikających ze wspólnego zamieszkania określonego miejsca ${ }^{29}$. Zgodnie $\mathrm{z}$ art. 1 ust. 1 i 2 u.g.k. gospodarka komunalna polega na wykonywaniu przez jednostki samorządu terytorialnego zadań własnych (wymienionych w art. 7 u.s.g,) w celu zaspokojenia zbiorowych potrzeb wspólnoty samorządowej. Obejmuje w szczególności zadania o charakterze użyteczności publicznej, których celem jest bieżące i nieprzerwane zaspokajanie zbiorowych potrzeb ludności w drodze świadczenia usług powszechnie dostępnych.

Zgodnie z art. 2 u.g.k. gospodarka komunalna może być prowadzona przez jednostki samorządu terytorialnego, w szczególności w formach zakładu budżetowego lub spółek prawa handlowego. Przepis art. 3 ust. 1 u.g.k. daje jednostkom

25 T. Kocowski, Komercjalizacja, prywatyzacja a podmioty administracji gospodarczej, „Przegląd Prawa i Administracji” 2015, nr 101, s. 287.

26 T. Kocowski, Prywatyzacja zarzadzania majątkiem publicznym, prywatyzacja majątkowa, prywatyzacja zadań publicznych i prywatyzacja wykonania zadań publicznych, [w:] Prawne aspekty prywatyzacji, s. 54.

27 Na podstawie ustawy z dnia 8 marca 1990 roku o samorządzie gminnym gmina może prowadzić również działalność gospodarczą wykraczającą poza zadania o charakterze użyteczności publicznej (art. 9 ust. 2 u.s.g.).

28 Ustawa z dnia 20 grudnia 1996 roku o gospodarce komunalnej (tekst jedn. Dz.U. z 2017 r. poz. 827).

29 J. Lang, Prawo gospodarki komunalnej, [w:] Prawo administracyjne, red. M. Wierzbowski, Warszawa 2003, s. 372. 
samorządu terytorialnego możliwość powierzenia wykonywania zadań z zakresu gospodarki komunalnej osobom fizycznym, osobom prawnym lub jednostkom organizacyjnym nieposiadającym osobowości prawnej, w drodze umowy na zasadach ogólnych - z uwzględnieniem przepisów ustawy z dnia 27 sierpnia 2004 roku o świadczeniach opieki zdrowotnej finansowanych ze środków publicznych ${ }^{30}$ oraz przepisów ustawy z dnia 27 sierpnia 2009 roku o finansach publicznych ${ }^{31}$ albo w trybie przepisów: ustawy z dnia 19 grudnia 2008 roku o partnerstwie publiczno-prywatnym ${ }^{32}$, ustawy z dnia 29 stycznia 2004 roku — Prawo zamówień publicznych ${ }^{33}$; ustawy z dnia 24 kwietnia 2003 roku o działalności pożytku publicznego i o wolontariacie ${ }^{34}$; ustawy z dnia 16 grudnia 2010 roku o publicznym transporcie zbiorowym ${ }^{35}$ oraz ustawy z dnia 21 października 2016 roku o umowie koncesji na roboty budowlane lub usługi ${ }^{36}$. Jeżeli do prowadzenia danego rodzaju działalności na podstawie innych ustaw jest wymagane uzyskanie zezwolenia, jednostki samorządu terytorialnego mogą powierzyć wykonywanie zadań wyłącznie podmiotowi posiadającemu wymagane zezwolenie (art. 3 ust. 2 u.g.k.).

Przepis art. 3 u.g.k. dał jednostkom samorządu terytorialnego możliwość zorganizowania innego niż dotychczas przewidzianego sposobu wykonywania przez nie zadań własnych (niekiedy obowiązkowych). Jeśli gmina sama rezygnuje z wykonywania zadań z zakresu gospodarki komunalnej, może zlecić ich wykonanie osobom trzecim. Według T. Kocowskiego mamy tu do czynienia z możliwością dokonania prywatyzacji wykonania zadań publicznych ${ }^{37}$.

Przedmiotem niniejszego opracowania jest prywatyzacja wykonania zadania ochrony przeciwpożarowej przez gminę, dlatego skupię się wyłącznie na krótkiej analizie podstaw prawnych powierzania wykonywania zadań z zakresu gospodarki komunalnej, jakim jest ochrona przeciwpożarowa, organizacjom pozarządowym, do których zaliczamy ochotnicze straże pożarne.

30 Ustawa z dnia 27 sierpnia 2004 roku o świadczeniach opieki zdrowotnej finansowanych ze środków publicznych (tekst jedn. Dz.U. z 2018 r. poz. 1510).

31 Ustawa z dnia 27 sierpnia 2009 roku o finansach publicznych (tekst jedn. Dz.U. z 2017 r. poz. 2077 ze zm).

32 Ustawa z dnia 19 grudnia 2008 roku o partnerstwie publiczno-prywatnym (tekst jedn. Dz.U. z 2017 r. poz. 1834).

33 Ustawa z dnia 29 stycznia 2004 roku — Prawo zamówień publicznych (tekst jedn. Dz.U. z 2017 r. poz. 1579 ze zm).

34 Ustawa z dnia 24 kwietnia 2003 roku o działalności pożytku publicznego i o wolontariacie (tekst jedn. Dz.U. z 2018 r. poz. 450 ze zm).

35 Ustawa z dnia 16 grudnia 2010 roku o publicznym transporcie zbiorowym (tekst jedn. Dz.U. z 2017 r. poz. 2136 ze zm).

36 Ustawa $z$ dnia 21 października 2016 roku o umowie koncesji na roboty budowlane lub usługi (Dz.U. z 2016 r. poz. 1920).

37 T. Kocowski, Prywatyzacja zarzadzania majątkiem..., s. 56. 


\section{Ochotnicze straże pożarne jako partner do prywatyzacji wykonania zadania ochrony przeciwpożarowej}

Zgodnie z art. 3 ust. 2 ustawy z dnia 24 kwietnia 2003 roku o działalności pożytku publicznego i o wolontariacie (dalej: u.d.p.w.) organizacjami pozarządowymi są organizacje niebędące jednostkami sektora finansów publicznych w rozumieniu ustawy z dnia 27 sierpnia 2009 roku o finansach publicznych lub przedsiębiorstwami, instytutami badawczymi, bankami i spółkami prawa handlowego będącymi państwowymi lub samorządowymi osobami prawnymi, niedziałające w celu osiągnięcia zysku - osoby prawne lub jednostki organizacyjne nieposiadające osobowości prawnej, którym odrębna ustawa przyznaje zdolność prawną, $\mathrm{w}$ tym fundacje i stowarzyszenia, $\mathrm{z}$ wyłączeniem fundacji utworzonych przez partie polityczne.

Według art. 12 Konstytucji RP stowarzyszenia są jedną z postaci „dobrowolnych zrzeszeń obywateli”, obok partii politycznych, związków zawodowych, organizacji społeczno-zawodowych rolników, ruchów obywatelskich, innych dobrowolnych zrzeszeń oraz fundacji, realizujących również i w tej formie wyrażoną w art. 58 Konstytucji RP wolność zrzeszania się ${ }^{38}$.

Sytuację prawną stowarzyszeń regulują przepisy ustawy z dnia 7 kwietnia 1989 roku - Prawo o stowarzyszeniach ${ }^{39}$ (dalej: u.p.s.). Według P. Sarnackiego prawo o stowarzyszeniach zajmuje się aspektami formalnoorganizacyjnymi powstawania i funkcjonowania tych jednostek. Nie zajmuje się natomiast posiadanymi przez nie uprawnieniami, które są pochodną wolności zrzeszania się, będącej z kolei pochodną zasady zwierzchnictwa narodu i uznania praw jednostki za zasadniczą podstawę i cel państwa ${ }^{40}$. Stowarzyszenia mogą działać wtedy, gdy zdaniem członków ich działanie się mieści w którymkolwiek z tych założeń konstytucyjnych (suwerenności narodu i wolnościowego statusu jednostki) i służy realizacji celów stowarzyszenia. Działanie stowarzyszenia, tak jak jednostki, musi mieścić się w granicach ustaw, nie musi natomiast zawsze legitymować się szczególną podstawą ustawową ${ }^{41}$. Zgodnie z orzeczeniem SN z dnia 23 lutego 1990 roku $^{42}$ sąd rejestrowy, rozpatrując sprawę o rejestrację stowarzyszenia, nie ocenia, czy jego utworzenie jest celowe. Jeżeli nawet najbardziej specyficzne czy

38 P. Sarnacki, Prawo o stowarzyszeniach. Komentarz, Warszawa 2007, s. 11.

39 Ustawa z dnia 7 kwietnia 1989 roku — Prawo o stowarzyszeniach (tekst jedn. Dz.U. z 2017 r. poz. 210 ze zm).

40 P. Sarnacki, op. cit., s. 12.

41 Ibidem, s. 13.

42 Orzeczenie Sądu Najwyższego z dnia 23 lutego 1990 roku, I PR 446/89, OSNC 1991, nr 7 , poz. 96. 
wręcz fantastyczne cele są zgodne z przepisami prawa, to z reguły każde stowarzyszenie powinno być zarejestrowane.

Artykuł 2 ust. 1 u.p.s. definiuje stowarzyszenie jako dobrowolne, samorządne, trwałe zrzeszenie o celach niezarobkowych. Dobrowolność oznacza możliwość swobodnego tworzenia nowego lub przystąpienia do istniejącego stowarzyszenia lub wystąpienia z niego. Samorządność wiąże się zarówno z niezależnością od podmiotów zewnętrznych, jak i z pełną swobodą podejmowania decyzji w sprawach stowarzyszenia (między innymi: w określaniu celów, programów działania i struktury organizacyjnej oraz w uchwalaniu norm wewnętrznych dotyczących jego działalności — art. 2 ust. 2 u.p.s.). Trwałość związana jest z trwałością celów stowarzyszenia, co przekłada się na istnienie stowarzyszenia niezależnie od zmieniającego się składu członków. Niezarobkowy cel oznacza, że nie można utworzyć stowarzyszenia, którego celem byłaby działalność zarobkowa. Nie można również przekształcić stowarzyszenia w instytucję realizującą takie cele. Ze względu na to, że stowarzyszenie opiera działalność na pracy społecznej swoich członków (art. 2 ust. 2 u.p.s.), ewentualne przychody z prowadzonej działalności gospodarczej nie mogą być dzielone między członków, lecz muszą być przekazane na cele statutowe ${ }^{43}$.

Zgodnie z art. 9 u.p.s. stowarzyszenie może założyć co najmniej siedem osób, które muszą uchwalić jego statut zgodnie z wymogami art. 10 ust. 1 u.p.s. ${ }^{44}$ oraz wybrać komitet założycielski albo władze stowarzyszenia. Wniosek w sprawie założenia stowarzyszenia podpisują wszyscy członkowie zarządu i podlega ono obowiązkowemu wpisowi do Krajowego Rejestru Sądowego. Ochotnicza straż pożarna (dalej: OSP) jako stowarzyszenie mające osobowość prawną uzyskaną po wpisie działa przez swoje organy. Najwyższą władzą stowarzyszenia jest walne zebranie członków (art. 11 ust. 1 u.p.s.). Stowarzyszenie jest zobowiązane do powołania zarządu oraz organu kontroli wewnętrznej (art. 11 ust. 3 u.p.s.). Zarząd nadzoruje działalność stowarzyszenia i reprezentuje je na zewnątrz.

43 A. Kidyba, Ustawa o fundacjach. Prawo o stowarzyszeniach, Warszawa 1997, s. 58 n.

44 Statut stowarzyszenia określa w szczególności:

1) nazwę stowarzyszenia, odróżniającą je od innych stowarzyszeń, organizacji i instytucji;

2) teren działania i siedzibę stowarzyszenia;

3) cele i sposoby ich realizacji;

4) sposób nabywania i utraty członkostwa, przyczyny utraty członkostwa oraz prawa i obowiązki członków;

5) władze stowarzyszenia, tryb dokonywania ich wyboru, uzupełniania składu oraz ich kompetencje;

6) możliwość otrzymywania przez członków zarządu wynagrodzenia za czynności wykonywane w związku z pełnioną funkcją;

7) sposób reprezentowania stowarzyszenia, w szczególności sposób zaciągania zobowiązań majątkowych, a także warunki ważności uchwał władz stowarzyszenia;

8) sposób uzyskiwania środków finansowych oraz ustanawiania składek członkowskich. 
OSP jest nietypowym stowarzyszeniem, ponieważ można zakwalifikować ją do społecznych organizacji ratowniczych ${ }^{45}$. Na jej status wpływa również to, że jest jednocześnie jednostką organizacyjną ochrony przeciwpożarowej na podstawie art. 15 pkt 6 ustawy z dnia 24 sierpnia 1991 roku o ochronie przeciwpożarowej (dalej: u.o.p. ${ }^{46}$.

Stowarzyszenie jako osoba prawna posiada swój majątek, którym są składki członkowskie, darowizny, spadki, zapisy, dochody z własnej działalności, dochody z majątku stowarzyszenia oraz z ofiarności publicznej (art. 33 ust. 1 u.p.s.). Stowarzyszenie, z zachowaniem obowiązujących przepisów, może przyjmować darowizny, spadki i zapisy oraz korzystać z ofiarności publicznej (art. 33 ust. 2 u.p.s.). Może też otrzymywać dotacje według zasad określonych we właściwych przepisach (art. 35 u.p.s.).

Zgodnie z art. 32 ust. 2 i 3 ustawy o ochronie przeciwpożarowej gmina ma obowiązek sfinansować szereg elementów z działalności OSP. Do elementów tych przepis ten zalicza: koszty wyposażenia, utrzymania, wyszkolenia i zapewnienia gotowości bojowej ochotniczej straży pożarnej ponosi gmina, przy czym szkolenie członków ochotniczej straży pożarnej prowadzi nieodpłatnie Państwowa Straż Pożarna. Gmina ma również obowiązek: bezpłatnego umundurowania członków ochotniczej straży pożarnej; ubezpieczenia w instytucji ubezpieczeniowej członków ochotniczej straży pożarnej i młodzieżowej drużyny pożarniczej; ponoszenia kosztów okresowych badań lekarskich. Ponadto zgodnie z art. 32 ust. $3 b$ u.o.p jednostki samorządu terytorialnego mogą przekazywać ochotniczym strażom pożarnym środki pieniężne w formie dotacji.

Przekazanie OSP środków pieniężnych w formie dotacji musi się opierać na ustawie z dnia 27 sierpnia 2009 roku o finansach publicznych (dalej: u.f.p.). Ustawa przewiduje trzy rodzaje dotacji: celową (art. 127 u.f.p.), przedmiotową (art. 130 u.f.p.) i podmiotową (art. 131 u.f.p.). Dotacje celowe to środki przeznaczone na finansowanie lub dofinansowanie zadań wymienionych w art. 127 u.f.p. ${ }^{47}$ Dotacje przedmiotowe są środkami przeznaczonymi na dopłaty do określonych rodzajów wyrobów lub usług, które mogą być udzielane na podstawie odrębnych ustaw lub przepisów Unii Europejskiej: dla przedsiębiorców wytwarzających określone rodzaje wyrobów lub świadczących określone rodzaje usług oraz dla podmiotów wykonujących zadania na rzecz rolnictwa $-\mathrm{z}$ uwzględnieniem ich równo-

45 T. Kocowski, Gmina a Ochotnicze Straże Pożarne..., s. 108.

46 Ustawa z dnia 24 sierpnia 1991 roku o ochronie przeciwpożarowej (tekst jedn. Dz.U. z 2018 r. poz. 620).

47 Dotacje celowe to środki przeznaczone na finansowanie lub dofinansowanie między innymi: zadań z zakresu administracji rządowej oraz innych zadań zleconych jednostkom samorządu terytorialnego ustawami; ustawowo określonych zadań, w tym zadań z zakresu mecenatu państwa nad kulturą, realizowanych przez jednostki inne niż jednostki samorządu terytorialnego; bieżących zadań własnych jednostek samorządu terytorialnego; zadań agencji wykonawczych; zadań zleconych do realizacji organizacjom pozarządowym; kosztów realizacji inwestycji; dopłaty do oprocentowania kredytów bankowych w zakresie określonym w odrębnych ustawach. 
prawności (art. 130 u.f.p.). Dotacje podmiotowe obejmują środki dla podmiotu wskazanego w odrębnej ustawie lub w umowie międzynarodowej wyłącznie na dofinansowanie działalności bieżącej w zakresie określonym w odrębnej ustawie lub umowie międzynarodowej (art. 131 u.f.p.).

W związku z tym, że OSP — zgodnie z art. 32 ust. 2 i 3 u.o.p. - otrzymuje środki finansowe na swoją statutową działalność (między innymi ochronę przeciwpożarową), należy podkreślić, że przekazane środki nie finansują zadań ochrony przeciwpożarowej nałożonych na gminę. Przekazane środki współfinansują tylko realizację celów statutowych OSP. Aby OSP mogło realizować zadanie ochrony przeciwpożarowej gminy nałożone art. 7 u.s.g., musi najpierw zlecić wykonanie tego zadania na podstawie ustawy z dnia 24 kwietnia 2003 roku o działalności pożytku publicznego i o wolontariacie.

\section{Przekazanie przez gminę zadania ochrony przeciwpożarowej OSP}

Przepisy ustawy z dnia 24 kwietnia 2003 roku o działalności pożytku publicznego i wolontariacie przewidują możliwość zlecania organizacjom pozarządowym realizacji zadań publicznych na zasadach określonych w jej przepisach. Aby możliwe było zlecenie wykonania zadania publicznego na przykład stowarzyszeniu (OSP) i przekazanie dotacji na ten cel, zadanie musi mieścić się w obszarze wymienionym w art. 4 u.d.p.w. Ponadto jednostka, której powierza się wykonanie zadania, musi prowadzić działalność statutową we wskazanym obszarze (art. 11 ust 1 pkt 2).

Artykuł 4 u.d.p.w. wymienia 39 obszarów, w tym w punkcie 20 - porządek i bezpieczeństwo publiczne oraz w punkcie 23 - ratownictwo i ochronę ludności. Zadanie publiczne wymienione w art. 7 u.s.g - ochronę przeciwpożarową — można zaliczyć do obu obszarów. Jeśli gmina chciałaby zlecić stowarzyszeniu zadanie publiczne, które nie mieści się w żadnym z obszarów wymienionych w art. 4 u.d.p.w., może to zrobić, ale już nie na podstawie przepisów ustawy z dnia 24 kwietnia 2003 roku o działalności pożytku publicznego i wolontariacie, lecz art. 221 ust. 2 i 4 ustawy o finansach publicznych. Na podstawie tego przepisu rada gminy/miasta, rada powiatu, sejmik województwa w drodze uchwały określa tryb postępowania o udzielenie dotacji, sposób jej rozliczenia oraz kontroli ${ }^{48}$.

Zlecanie organizacjom pozarządowym realizacji zadań publicznych odbywa się najczęściej po przeprowadzeniu otwartego konkursu ofert, chyba że przepisy odrębne przewidują w sytuacji nadzwyczajnej inny tryb zlecania (art. 11a, art. 11b, art. 11c u.d.p.w.). Artykuł 11c u.d.p.w. przewiduje pominięcie otwartego

48 Zob. E. Hadrowicz, Prawo o stowarzyszeniach. Komentarz, Warszawa 2016, s. 297 n. 
konkursu ofert przez ministra właściwego do spraw wewnętrznych w przypadkach dotyczących zadań z zakresu ochrony ludności i ratownictwa zleconych między innymi jednostkom ochrony przeciwpożarowej, o których mowa w art. 15 pkt 6 i 7 ustawy z dnia 24 sierpnia 1991 roku o ochronie przeciwpożarowej ${ }^{49}$.

Ustawa o działalności pożytku publicznego i o wolontariacie określa również ramy prawne otwartego konkursu. Artykuł 13 tej ustawy nakłada na organ administracji publicznej obostrzenia odnośnie do warunków, które powinien spełniać ten konkurs. Ogłoszenie otwartego konkursu ofert powinno zawierać między innymi informacje o: rodzaju zadania; wysokości środków publicznych przeznaczonych na jego realizację; zasadach przyznawania dotacji; terminach i warunkach realizacji zadania; terminie składania ofert; trybie i kryteriach stosowanych przy wyborze ofert oraz terminie dokonania wyboru; ofertach zrealizowanych przez organ administracji publicznej w roku ogłoszenia otwartego konkursu i zadaniach publicznych tego samego rodzaju i związanych z nimi kosztach w roku poprzednim, ze szczególnym uwzględnieniem wysokości dotacji przekazanych organizacjom pozarządowym i innym podmiotom. Otwarty konkurs ofert powinien być ogłoszony w Biuletynie Informacji Publicznej, w siedzibie organu administracji publicznej (w miejscu przeznaczonym do zamieszczania ogłoszeń) oraz na stronie internetowej organu administracji publicznej. Ogłoszenie otwartego konkursu ofert można również zamieścić w dzienniku lub tygodniku o zasięgu ogólnopolskim, regionalnym lub lokalnym, w zależności od rodzaju zadania publicznego. Termin składania ofert nie może być krótszy niż od dnia ukazania się ogłoszenia.

Do konkursów ogłoszonych przed 3 września 2016 roku stosowano zasady rozporządzenia Ministra Pracy i Polityki Społecznej z dnia 15 grudnia 2010 roku w sprawie wzoru oferty i ramowego wzoru umowy dotyczących realizacji zadania publicznego oraz wzoru sprawozdania $z$ wykonania tego zadania ${ }^{50}$, a do konkursów ogłaszanych od 3 września 2016 roku stosuje się zasady rozporządzenia Ministra Rodziny, Pracy i Polityki Społecznej z dnia 17 sierpnia 2016 roku w sprawie wzorów ofert i ramowych wzorów umów dotyczących realizacji zadań publicznych oraz wzorów sprawozdań z wykonania tych zadań ${ }^{51}$. Rozporządzenia te są aktami wykonawczymi do ustawy o działalności pożytku publicznego i wolontariacie.

49 Zob. J. Blicharz, Powierzanie wykonywania zadań publicznych w drodze umownej, [w:] Wspótczesne europejskie problemy prawa administracyjnego i administracji publicznej, „Prawo” 295, 2005, s. 63 n.

50 Rozporządzenie Ministra Pracy i Polityki Społecznej z dnia 15 grudnia 2010 roku w sprawie wzoru oferty i ramowego wzoru umowy dotyczących realizacji zadania publicznego oraz wzoru sprawozdania z wykonania tego zadania (Dz.U. z 2011 r. Nr 6 poz. 25). Rozporządzenie uchylono 3 września 2016 roku.

51 Rozporządzenie Ministra Rodziny, Pracy i Polityki Społecznej z dnia 17 sierpnia 2016 roku w sprawie wzorów ofert i ramowych wzorów umów dotyczących realizacji zadań publicznych oraz wzorów sprawozdań z wykonania tych zadań (Dz.U. z 2016 r. poz. 1300). 
Jeżeli zlecenie wykonania zadania nie będzie realizowane na podstawie przepisów ustawy o działalności pożytku publicznego i wolontariacie, organizacje pozarządowe przyjmujące zlecenie realizacji zadania publicznego zobowiązują się do wykonania go $\mathrm{w}$ zakresie i na zasadach określonych $\mathrm{w}$ umowie sporządzonej z uwzględnieniem przepisów art. 151 ust. 2 i art. 221 ust. 3 ustawy z dnia 27 sierpnia 2009 roku o finansach publicznych, a organ administracji publicznej zobowiązuje się do przekazania dotacji na realizację zadania. Umowa wymaga formy pisemnej pod rygorem nieważności. Powinna ona zawierać: szczegółowy opis zadania, w tym cel, na jaki dotacja została przyznana, i termin jego wykonania; wysokość udzielonej dotacji i tryb płatności; termin wykorzystania dotacji, nie dłuższy niż do dnia 31 grudnia danego roku budżetowego; tryb kontroli wykonywania zadania; termin i sposób rozliczenia udzielonej dotacji; termin zwrotu niewykorzystanej części dotacji, nie dłuższy niż 15 dni od określonego w umowie dnia wykonania zadania.

\section{Bibliografia}

Boć J., Obywatel wobec ingerencji współczesnej administracji, Wrocław 1985.

Biernat S., Prywatyzacja zadań publicznych, Warszawa-Kraków 1994.

Blicharz J., Powierzanie wykonywania zadań publicznych w drodze umownej, [w:] Wspótczesne europejskie problemy prawa administracyjnego i administracji publicznej, ,Prawo 295”, 2005.

Błaś A., Formy działania administracji w warunkach prywatyzacji zadań publicznych, [w:] Administracja i prawo administracyjne u progu trzeciego tysiaclecia. Materiaty konferencji naukowej katedr prawa i postępowania administracyjnego, Łódź 2000.

Błaś A., Prywatyzacja zadań samorządu terytorialnego, [w:] Studia nad samorzadem terytorialnym, red. A. Błaś, Wrocław 2002.

Borkowski A., Interes publiczny a partnerstwo publiczno-prywatne, [w:] Prawne aspekty prywatyzacji, red. J. Blicharz, Wrocław 2012.

Dobkowski J., Struktura interesu społecznego a zasady rozdzielenia odpowiedzialności publicznoprawnej w administracji, [w:] Jednostka, państwo, administracja. Nowy wymiar, red. E. Ura, Rzeszów 2004.

Elżanowski M., Kompetencje rad nadzorczych i terenowych organów administracji państwowej, [w:] Terenowe organy administracji i rady narodowe po reformie, red. J. Służewski, Warszawa 1977.

Gronkiewicz-Waltz H., Rola ministra przemysłowego w zarządzaniu gospodarka państwowa, Warszawa 1985.

Hadrowicz E., Prawo o stowarzyszeniach. Komentarz, Warszawa 2016.

Kieres L., Samorzadowy sektor gospodarczy, [w:] System Prawa Administracyjnego, red. R. Hauser, Z. Niewiadomski, A. Wróbel, t. 8B. J. Grabowski, L. Kieres, A. Walaszek-Pyzioł, R. Blicharz, T. Długosz, K. Horubski, K. Kiczka, M. Pawełczyk, M. Swora, M. Szydło, T. Włudyka, A. Żurawik, Publiczne prawo gospodarcze, Warszawa 2013.

Kidyba A., Ustawa o fundacjach. Prawo o stowarzyszeniach, Warszawa 1997.

Kocowski T., Gmina a Ochotnicze Straże Pożarne w wykonywaniu zadań w zakresie ochrony przeciwpożarowej, [w:] Prawo i administracja wobec współczesnych problemów społecznych i gospodarczych, red. T. Kocowski, W. Małecki, „Prawo” 323, 2017. 
Kocowski T., Komercjalizacja, prywatyzacja a podmioty administracji gospodarczej, „Przegląd Prawa i Administracji” 2015, nr 101.

Kocowski T., Prywatyzacja zarządzania majątkiem publicznym, prywatyzacja majątkowa, prywatyzacja zadań publicznych i prywatyzacja wykonania zadań publicznych, [w:] Prawne aspekty prywatyzacji, red. J. Blicharz, Wrocław 2012.

Kocowski T., Paplicki, M., Ratownictwo medyczne - czy wyłacznie państwowe?, [w:] Prawne aspekty prywatyzacji, red. J. Blicharz, Wrocław 2012.

Korczak J., Cedrowicz, D., Dywersyfikacja zadań samorzadu terytorialnego, [w:] Organizacja administracji publicznej z perspektywy powierzonych jej zadań, red. T. Bąkowski, Warszawa 2015.

Lang J., Prawo gospodarki komunalnej, [w:] Prawo administracyjne, red. M. Wierzbowski, Warszawa 2003.

Prawo administracyjne, red. J. Boć, Wrocław 2010.

Sarnacki P., Prawo o stowarzyszeniach. Komentarz, Warszawa 2007.

Walaszek-Pyzioł, A., Samodzielność prawna przedsiębiorstwa państwowego, Kraków 1984.

Zacharko L., Prywatyzacja zadań publicznych gminy. Studium administracyjnoprawne, Katowice 2000 .

\section{Wykaz aktów prawnych}

Konstytucja Rzeczypospolitej Polskiej z dnia 2 kwietnia 1997 roku uchwalona przez Zgromadzenie Narodowe w dniu 2 kwietnia 1997 roku, przyjęta przez Naród w referendum konstytucyjnym w dniu 25 maja 1997 roku, podpisana przez Prezydenta Rzeczypospolitej Polskiej w dniu 16 lipca 1997 roku (Dz.U. z 1997 r. Nr 78 poz. 483 ze. zm.).

Ustawa z dnia 7 kwietnia 1989 roku — Prawo o stowarzyszeniach (Dz.U. z 1989 r. Nr 20, poz. 104 ze zm.).

Ustawa z dnia 8 marca 1990 roku o samorządzie gminnym (Dz.U. z 1990 r. Nr 16, poz. 95 ze zm.).

Ustawa z dnia 24 sierpnia 1991 roku o ochronie przeciwpożarowej (Dz.U. z 1991 r. Nr 81, poz. 351 ze zm.).

Ustawa z dnia 20 grudnia 1996 roku o gospodarce komunalnej (Dz.U. z 1997 r. Nr 9, poz. 43 ze zm.).

Ustawa ustawy z dnia 24 kwietnia 2003 roku o działalności pożytku publicznego i o wolontariacie (Dz.U. z 2003 r. Nr 96, poz. 873 ze zm.).

Ustawa z dnia 29 stycznia 2004 roku — Prawo zamówień publicznych (Dz.U. z 2004 r. Nr 19, poz. 177 ze zm.).

Ustawa z dnia 27 sierpnia 2004 roku o świadczeniach opieki zdrowotnej finansowanych ze środków publicznych (Dz.U. z 2004 r. Nr 210, poz. 2135 ze zm.).

Ustawa z dnia 19 grudnia 2008 roku o partnerstwie publiczno-prywatnym (Dz.U. z 2009 r. Nr 19, poz. $100 \mathrm{ze} \mathrm{zm}$.).

Ustawa z dnia 27 sierpnia 2009 roku o finansach publicznych (Dz.U. z 2009 r. Nr 157, poz. 1240 ze $\mathrm{zm}$.).

Ustawa z dnia 16 grudnia 2010 roku o publicznym transporcie zbiorowym (Dz.U. z 2003 r. Nr 96, poz. 873 ze zm.).

Ustawa z dnia 21 października 2016 roku o umowie koncesji na roboty budowlane lub usługi (Dz.U. z 2016 r. poz. 1920 ze zm.). 


\title{
Wykaz orzecznictwa
}

Orzeczenie Sądu Najwyższego z dnia 23 lutego 1990 roku, I PR 446/89, OSNC 1991, nr 7, poz. 96. Orzeczenie Trybunału Konstytucyjnego z dnia 27 września 1994 roku, sygn. K. 10/93, OTK 1994, cz. 2, poz. 46.

Wyrok Sądu Najwyższego z dnia 8 lutego 1996 roku, III ARW 64/95, „Wspólnota” 1996, nr 43, s. 26.

\section{Privatization of the performance of the fire protection task by the commune}

\begin{abstract}
Summary
Under the influence of political factors, the state decides which public tasks it will carry out through its organs, which will be transferable to other entities of public authority or non-public entities. Government and local government implements many public tasks. In confrontation with emerging new problems to be solved, rapidly changing social reality and growing needs of society, these administrations are not able to perform all public tasks assumed on themselves. It seems, therefore, that the optimal solution for this phenomenon is to free themselves from performing these tasks by transferring them to private entities for execution.
\end{abstract}

Keywords: privatization of the task, fire protection, volunteer fire brigades. 